\title{
Evaluation of Student Learning Outcomes on Square Materials with Problem-Based Learning Model
}

\author{
Erpin Evendi*, Nur Hardiani \\ Faculty of Tarbiyah and Teacher Training, Universitas Islam Negeri Mataram, Indonesia \\ *Corresponding Author e-mail: erpin_evendi@uinmataram.ac.id
}

Received: November 2021; Revised: November 2021; Published: December 2021

\begin{abstract}
Good knowledge construction is a guarantee of achieving better learning outcomes. In the context of our current study, the PBL model is implemented in the classroom and further evaluation of students' cognitive learning outcomes is carried out. Specifically, the purpose of this study is to evaluate student learning outcomes on square material in the application of the PBL model. This research is a quasi-experimental with pretest-posttest control group design. The number of research samples for each group was 25 students in a private Islamic school (equivalent to a secondary school) in Mataram, Indonesia. Data on student learning outcomes was collected using a learning outcome test instrument on square material. Descriptive and statistical analysis was carried out on student learning outcomes data, this was analyzed using the SPSS.23 tool. The results of the study show the advantages of the PBL model in improving student learning outcomes when compared to conventional learning. Finally, we recommend the use of this model in learning mathematics to improve student learning outcomes.
\end{abstract}

Keywords: Problem-Based Learning Model, Learning Outcomes

How to Cite: Evendi, E., \& Hardiani, N. (2021). Evaluation of Student Learning Outcomes on Square Materials With Problem-Based Learning Model. Prisma Sains : Jurnal Pengkajian Ilmu dan Pembelajaran Matematika dan IPA IKIP Mataram, 9(2), 295-300. doi:https://doi.org/10.33394/j-ps.v9i2.4390

https://doi.org/10.33394/j-ps.v9i2.4390

Copyright $\odot$ 2021, Evendi \& Hardiani This is an open-access article under the CC-BY License.

\section{INTRODUCTION}

Mathematics is a universal science that underlies the development of modern technology, has an important role in scientific disciplines and advances human thinking (Belbase et al., 2021; Hillmayr et al., 2020). Rapid developments in the fields of technology, information and communication today are based on the development of mathematics in many content (Viberg et al., 2020). Generally, mathematics lessons at school are often one of the subjects that are often feared and disliked by most students. Mathematics is an abstract, theoretical science, full of symbols and formulas that are difficult and confusing, and this is an unpleasant learning experience in mathematics. Such thinking will clearly affect individual mathematics mastery because negative perceptions have existed due to their previous learning experiences (Salamah, 2020). As a result, mathematics lessons are no longer viewed objectively, they are not interested in mathematics before trying it. Basically, the implication of learning mathematics is to encourage students' initiative and give them the opportunity to think differently, encourage curiosity, the ability to argue and predict, appreciate discoveries as useful (Palmér \& Johansson, 2018). In learning, the teacher has the task of encouraging, guiding and as a learning facilitator for students, and is responsible for seeing everything that happens in the classroom to help the student's development process (Li \& Stylianides, 2018).

In reality, in the field, the process of learning mathematics is not always accompanied by ease in achieving learning objectives as expected. Until now, mathematics learning activities in schools have not shown satisfactory results. This can be seen from the results of a 
survey by TIMSS (Third International Mathematics and Science Study) and PISA (Programme International for Students Assessment), where the results of TIMSS show that Indonesian secondary school students are ranked 34th out of 38 countries, while in PISA in 2015 was ranked 63 out of 70 countries. The results of the two studies indicate that Indonesia needs to make improvements in mathematics learning (Nurvicalesti \& Dewi, 2019). Students must be given the opportunity to develop their potential so that they are able to use mathematics as a tool to develop effective reasoning (Morsanyi et al., 2018). Low mathematics learning outcomes were also found in one secondary school in Mataram, Indonesia. Based on the results of field observations, it was found that the low student learning outcomes were because the learning mode applied by the teacher still emphasized expository which was dominated by teacher activities. This does not provide space for students to develop their thinking and closes the interaction space that supports good achievement in learning mathematics.

The ability of teachers to design or implement innovative learning is very necessary, this is of course adapted to the interests and talents and according to the level of student development. Teachers need to create situations where students can be active, creative, and responsive both physically and mentally (Darling-Hammond et al., 2020). On the one hand, in learning mathematics students must also build it for themselves, explore, describe, discuss, describe, investigate and solve problems, so that learning becomes more effective for the purpose of improving student learning outcomes. The teacher factor plays an important role in creating a learning atmosphere that is able to optimize students' reasoning, ideally, they have learning innovations that can help improve student learning outcomes (Kohlmeier \& Saye, 2019). One of the efforts that can be taken is by applying a more effective learning model, one of which is the Problem Based Learning (PBL) model. PBL is a student-centered interactive learning model that emphasizes providing authentic problems to students related to everyday life, and in groups looking for alternative solutions to solve these problems (Good et al., 2008; Kumar \& Natarajan, 2007). The learning principles in the PBL model include providing authentic problems that are close to real life and may occur in real life, active student involvement in learning, encouraging the use of various approaches in problem solving, giving students opportunities to make problem-solving choices, encouraging collaborative learning, and achievement of better learning outcomes.

Theoretical support that strengthens the PBL model as one of the superior learning models in improving student learning outcomes is because this model adheres to constructivist principles (Darling-Hammond et al., 2020). In PBL learning, students' active participation occurs through meaningful learning (Aarto-Pesonen \& Piirainen, 2020). When students learn in a community or group to solve problems, they are actually in the process of constructing knowledge (Kimmerle et al., 2015). Good knowledge construction is a guarantee of achieving better learning outcomes. In the context of our current study, the PBL model is implemented in the classroom and further evaluation of students' cognitive learning outcomes is carried out. Specifically, the purpose of this study is to evaluate student learning outcomes on square material in the application of the problem-based learning model.

\section{METHOD}

This research is a quasi-experimental with pretest-posttest control group design, where this design has a control group, but cannot fully function to control external variables that affect the implementation of the experiment. The research sample consisted of experimental $(\mathrm{N}=25)$ and control $(\mathrm{N}=25)$ groups. The learning experimental group uses a broblem based learning model, while the control group uses conventional learning. The research was conducted at a private Islamic school (equivalent to a secondary school) in the city of Mataram, Indonesia. First, both groups were given a pretest, then treatment in both classes, and finally a posttest. 


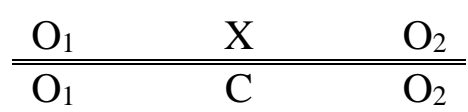

$\mathrm{O} 1$, the pretest was given to the experimental and control groups; O2, the posttest was given to the experimental and control groups; $\mathrm{X}$, the treatment of learning with the PBL model in the experimental group; $\mathrm{C}$, conventional learning treatment in the control group. The implementation of learning in each group was carried out for 2 meetings (excluding pretest and posttest), learning was carried out on square material.

Learning instruments include syllabus, lesson plans, and test instruments. All three refer to the planning for the implementation of the PBL model. The syllabus contains a general lesson plan that will be achieved in one learning period, while the lesson plan is a lesson plan for one meeting. Before being implemented, the three learning instruments were validated (content and construct) by three validators. Validity criteria with a range from very valid to invalid. This was adopted from a previous study (Prayogi et al., 2018).

Data on student learning outcomes was collected using a learning outcome test instrument on square material. The number of questions consists of twelve items covering cognitive learning outcomes at levels $\mathrm{C} 2$ to $\mathrm{C} 4$. The criteria for student learning outcomes in several score ranges are presented in Table 1.

Table 1. criteria for student learning outcomes

\begin{tabular}{cc}
\hline Score range & Criteria \\
\hline$L A \geq 80$ & Very good \\
$60 \leq L A<80$ & Good \\
$40<L A \leq 60$ & Enough \\
$20<L A \leq 40$ & Less \\
$L A \leq 20$ & Fail \\
\hline
\end{tabular}

The n-gain analysis was used to evaluate the increase in student learning outcomes scores, where the success of the PBL model at the implementation stage if on average the ngain criteria were "moderate", and student learning outcomes were in the "good" category. The n-gain analysis used Hake's formulation (Hake, 1999). Learning outcomes data were analyzed statistically (Anova test) using SPSS.23 tools.

\section{RESULTS AND DISCUSSION}

Analysis of student learning outcomes on square material with a problem-based learning model has been carried out in both groups (experimental and control). Descriptive analysis on pretest and posttest as presented in Table 1 .

Table 2. Student learning outcomes in each group

\begin{tabular}{lccccccc}
\hline \multirow{2}{*}{ Sample group } & \multirow{2}{*}{$\mathrm{N}$} & \multicolumn{4}{c}{ learning outcomes and criteria } & \multirow{2}{*}{ n-gain } & \multirow{2}{*}{ Criteria } \\
\cline { 3 - 6 } & & Pretest & Criteria & Posttest & Criteria & & \\
\hline Experiment & 25 & 38.60 & Less & 76.18 & Good & 0,71 & High \\
Control & 25 & 39.00 & Less & 40.00 & Less & 0,16 & Low \\
\hline
\end{tabular}

The results in Table 2 show that the mean pretest scores for the experimental and control groups were 38.60 and 39.00, respectively, both of which were "less." After the implementation of the PBL model, the posttest results showed an increase in learning outcomes in the experimental group, where an average score of 76.18 was obtained with the criteria of "good," while the control group still had the criteria of "less." The increase in learning outcomes scores for the experimental and control groups, respectively, with the criteria of "high" (n-gain score of 0.71) and "low" (n-gain score of 0.16). Furthermore, statistical analysis was used to evaluate the differences in student learning outcomes between the experimental and control groups. In the context of this study, we used one-way Anova analysis. Before this was realized, each group of data (pretest and posttest) was tested for normality and homogeneity, as presented in Table 3. 
Table 3. The result of normality and homogeneity test

\begin{tabular}{lcccc}
\hline \multirow{2}{*}{ Group of data } & \multicolumn{2}{c}{ Normality test (Kol.-Smir. test) } & \multicolumn{2}{c}{ Homogeneity test (Levene's test) } \\
\cline { 2 - 5 } & $\mathrm{N}$ & Sig. & Levene's test score & Sig. \\
\hline Pretest & 50 & 0,200 & 0,000 & 0,992 \\
Posttest & 50 & 0,200 & 0,970 & 0,331 \\
\hline
\end{tabular}

The results of the normality and homogeneity tests showed a significance of both $>0.05$. That is, the data is normally distributed, and the data variance is homogeneous. Based on the results of this prerequisite test, the analysis of differences in learning outcomes between the experimental and control classes can use one-way Anova analysis, as shown in Table 4.

Table 4. The results of one-way anova analysis

\begin{tabular}{lrrrrr}
\hline Group & Sum of squares & Df & Mean square & F & Sig. \\
\hline Between Groups & 1836.531 & 1 & 1956.500 & 619.198 & 0.000 \\
Within Groups & 135.750 & 48 & 3.245 & & \\
Total & 1972.281 & 49 & & & \\
\hline
\end{tabular}

The result of one-way anova analysis shows that the significance of testing (0.000) is less than the result of alpha testing $(<0.05)$. This shows that there is a significant difference between student learning outcomes in the experimental group and the control group.

The results of the analysis in Tables 2 to 4 have shown the advantages of learning with the PBL model compared to conventional learning. This is in accordance with the findings of previous studies that student performance in the context of learning achievement in mathematics is better when using the PBL model (Wewe, 2017). Mathematical problemsolving abilities and student learning responsibilities were also found to be better when learning using the PBL model (Dary et al., 2021). In PBL, the teacher's role is as a facilitator and coach of learning, and builds positive interactions (reciprocal relationships) between teachers and students (Li \& Stylianides, 2018). The success of PBL in improving learning outcomes cannot be separated from its superior features, namely a problem-driven content structure, a collaborative learning process, and a student-centered approach (Li \& Stylianides, 2018). In PBL, content is organized as problems involving unstructured, authentic, and contextual situations (Goodnough \& Hung, 2008). The relevance of authentic problems related to real life can help students build new knowledge. The social constructivist perspective is at the core of PBL where students build socially situated interaction, collaboration, and communication. PBL is also a student-centered learning that can develop critical thinking skills, problem solving skills, communication skills and lifelong learning (Ali, 2019).

\section{CONCLUSION}

The results of the study showed that the average pretest scores for the experimental and control groups were 38.60 and 39.00, respectively, both of which were "less." After the implementation of the PBL model, the posttest results showed an increase in learning outcomes in the experimental group, where an average score of 76.18 was obtained with the criteria of "good," while the control group still had the criteria of "less." The increase in learning outcomes scores for the experimental and control groups, respectively, with the criteria of "high" (n-gain score of 0.71) and "low" (n-gain score of 0.16). Statistical analysis shows that there is a significant difference between student learning outcomes in the experimental group and the control group.

\section{ACKNOWLEDGMENT}

This study is an independent study by lecturers as a form of responsibility for research assignments. Thank you to those who helped with this research process. 


\section{REFERENCES}

Aarto-Pesonen, L., \& Piirainen, A. (2020). Teacher students' meaningful learning in widening learning worlds. Teaching Education, 31(3), 323-342. https://doi.org/10.1080/10476210.2018.1561662

Ali, S. S. (2019). Problem Based Learning: A Student-Centered Approach. English Language Teaching, 12(5), 73-78.

Belbase, S., Mainali, B. R., Kasemsukpipat, W., Tairab, H., Gochoo, M., \& Jarrah, A. (2021). At the dawn of science, technology, engineering, arts, and mathematics (STEAM) education: Prospects, priorities, processes, and problems. International Journal of Mathematical Education in Science and Technology, 0(0), 1-37. https://doi.org/10.1080/0020739X.2021.1922943

Darling-Hammond, L., Flook, L., Cook-Harvey, C., Barron, B., \& Osher, D. (2020). Implications for educational practice of the science of learning and development. Applied Developmental Science, 24(2), 97-140. https://doi.org/10.1080/10888691.2018.1537791

Dary, N. W., Wijayanti, K., \& Winarti, E. R. (2021). Analysis of student's mathematical problem solving ability based on responsibility learning with themed problem based learning model. Unnes Journal of Mathematics Education, 10(2), Article 2. https://doi.org/10.15294/ujme.v10i2.26516

Good, J., Howland, K., \& Thackray, L. (2008). Problem-based learning spanning real and virtual words: A case study in Second Life. ALT-J, 16(3), 163-172. https://doi.org/10.1080/09687760802526681

Goodnough, K., \& Hung, W. (2008). Engaging Teachers' Pedagogical Content Knowledge: Adopting a Nine-Step Problem-Based Learning Model. Interdisciplinary Journal of Problem-Based Learning, 2(2). https://doi.org/10.7771/1541-5015.1082

Hillmayr, D., Ziernwald, L., Reinhold, F., Hofer, S. I., \& Reiss, K. M. (2020). The potential of digital tools to enhance mathematics and science learning in secondary schools: A context-specific meta-analysis. Computers \& Education, 153, 103897. https://doi.org/10.1016/j.compedu.2020.103897

Kimmerle, J., Moskaliuk, J., Oeberst, A., \& Cress, U. (2015). Learning and Collective Knowledge Construction With Social Media: A Process-Oriented Perspective. Educational Psychologist, 50(2), 120-137. https://doi.org/10.1080/00461520.2015.1036273

Kohlmeier, J., \& Saye, J. (2019). Examining the relationship between teachers' discussion facilitation and their students' reasoning. Theory \& Research in Social Education, 47(2), 176-204. https://doi.org/10.1080/00933104.2018.1486765

Kumar, M., \& Natarajan, U. (2007). A problem-based learning model: Showcasing an educational paradigm shift. The Curriculum Journal, 18(1), 89-102. https://doi.org/10.1080/09585170701292216

Li, H.-C., \& Stylianides, A. J. (2018). An examination of the roles of the teacher and students during a problem-based learning intervention: Lessons learned from a study in a Taiwanese primary mathematics classroom. Interactive Learning Environments, 26(1), 106-117. https://doi.org/10.1080/10494820.2017.1283333

Morsanyi, K., Prado, J., \& Richland, L. E. (2018). Editorial: The role of reasoning in mathematical thinking. Thinking \& Reasoning, 24(2), 129-137. https://doi.org/10.1080/13546783.2018.1435425

Nurvicalesti, N., \& Dewi, N. R. (2019). Kemampuan Literasi Matematika pada Pembelajaran Survey, Question, Read, Reflect, Recite, Review (SQ4R) berpendekatan Realistik. 2, 6.

Palmér, H., \& Johansson, M. (2018). Combining entrepreneurship and mathematics in primary school - what happens? Education Inquiry, 9(4), 331-346. https://doi.org/10.1080/20004508.2018.1461497 
Prayogi, S., Yuanita, L., \& Wasis. (2018). Critical Inquiry Based Learning: A Model of Learning to Promote Critical Thinking Among Prospective Teachers of Physic. Journal of Turkish Science Education, 15(1), 43-56.

Salamah, D. P. (2020). Analisis Kesalahan berdasarkan Newman Error Analysis terhadap Materi Peluang Kejadian Majemuk Ditinjau dari Gender dan Self Confidence pada Siswa Kelas XII SMK di Bandung Barat. JPMI (Jurnal Pembelajaran Matematika Inovatif), 3(4), 273-284. https://doi.org/10.22460/jpmi.v3i4.p\%p

Viberg, O., Grönlund, Å., \& Andersson, A. (2020). Integrating digital technology in mathematics education: A Swedish case study. Interactive Learning Environments, O(0), 1-12. https://doi.org/10.1080/10494820.2020.1770801

Wewe, M. (2017). The Effect of Problem Based Learning Model and Mathematic-Logical Intelligence Toward Mathematics Learning Achievement. Journal of Education Technology, 1(1), 13-17. https://doi.org/10.23887/jet.v1i1.10079 